\title{
Trichoderma Strains and Metabolites Selectively Increase the Production of Volatile Organic Compounds (VOCs) in Olive Trees
}

\author{
Irene Dini ${ }^{1,+}{ }^{(D)}$, Roberta Marra ${ }^{2, *}++^{\mathbb{D}}$, Pierpaolo Cavallo ${ }^{3,4} \mathbb{D}^{\mathbb{D}}$, Angela Pironti ${ }^{2}$, Immacolata Sepe ${ }^{5}$, \\ Jacopo Troisi ${ }^{6,7}$ (D), Giovanni Scala ${ }^{7}$, Pasquale Lombari ${ }^{2}$ and Francesco Vinale ${ }^{8,9}$
}

check for updates

Citation: Dini, I.; Marra, R.; Cavallo, P.; Pironti, A.; Sepe, I.; Troisi, J.; Scala, G.; Lombari, P.; Vinale, F. Trichoderma Strains and Metabolites Selectively Increase the Production of Volatile Organic Compounds (VOCs) in Olive Trees. Metabolites 2021, 11, 213. https: / / doi.org/10.3390/ metabo11040213

Academic Editor: Grégory Mouille

Received: 2 February 2021

Accepted: 26 March 2021

Published: 31 March 2021

Publisher's Note: MDPI stays neutral with regard to jurisdictional claims in published maps and institutional affiliations.

Copyright: (C) 2021 by the authors. Licensee MDPI, Basel, Switzerland. This article is an open access article distributed under the terms and conditions of the Creative Commons Attribution (CC BY) license (https:/ / creativecommons.org/licenses/by/ $4.0 /)$.
1 Department of Pharmacy, University of Naples Federico II, 80141 Naples, Italy; irdini@unina.it

2 Department of Agricultural Sciences, University of Naples Federico II, Portici, 80055 Naples, Italy; angela.pironti@unina.it (A.P.); pasquale.lmb@gmail.com (P.L.)

3 Department of Physics "E.R. Caianiello", University of Salerno, Fisciano, 84084 Salerno, Italy; pcavallo@unisa.it

4 Institute for Complex Systems, National Research Council, 00185 Rome, Italy

5 Diagnostica Cavallo S.r.l.—Centro di Ricerca Albo MIUR, 84123 Salerno, Italy; immasepe@gmail.com

6 Department of Chemistry and Biology "A. Zambelli", University of Salerno, Baronissi, 84081 Salerno, Italy; jtroisi@unisa.it

7 Theoreo S.r.l., Montecorvino Pugliano, 84090 Salerno, Italy; info@theoreosrl.com

8 Department of Veterinary Medicine and Animal Productions, University of Naples Federico II, 80138 Naples, Italy; frvinale@unina.it

9 Institute for Sustainable Plant Protection, National Research Council, Portici, 80055 Naples, Italy

* Correspondence: robmarra@unina.it

$\dagger$ These authors contributed equally to this work.

Abstract: Plants emit volatile organic compounds (VOCs) that induce metabolomic, transcriptomic, and behavioral reactions in receiver organisms, including insect pollinators and herbivores. VOCs' composition and concentration may influence plant-insect or plant-plant interactions and affect soil microbes that may interfere in plant-plant communication. Many Trichoderma fungi act as biocontrol agents of phytopathogens and plant growth promoters. Moreover, they can stimulate plant defense mechanisms against insect pests. This study evaluated VOCs' emission by olive trees (Olea europaea L.) when selected Trichoderma fungi or metabolites were used as soil treatments. Trichoderma harzianum strains M10, T22, and TH1, T. asperellum strain KV906, T. virens strain GV41, and their secondary metabolites harzianic acid (HA), and 6-pentyl- $\alpha$-pyrone (6PP) were applied to olive trees. Charcoal cartridges were employed to adsorb olive VOCs, and gas chromatography mass spectrometry (GC-MS) analysis allowed their identification and quantification. A total of 45 volatile compounds were detected, and among these, twenty-five represented environmental pollutants and nineteen compounds were related to olive plant emission. Trichoderma strains and metabolites differentially enhanced VOCs production, affecting three biosynthetic pathways: methylerythritol 1-phosphate (MEP), lipid-signaling, and shikimate pathways. Multivariate analysis models showed a characteristic fingerprint of each plant-fungus/metabolite relationship, reflecting a different emission of VOCs by the treated plants. Specifically, strain M10 and the metabolites 6PP and HA enhanced the monoterpene syntheses by controlling the MEP pathway. Strains GV41, KV906, and the metabolite HA stimulated the hydrocarbon aldehyde formation (nonanal) by regulating the lipid-signaling pathway. Finally, Trichoderma strains GV41, M10, T22, TH1, and the metabolites HA and 6PP improve aromatic syntheses at different steps of the shikimate pathway.

Keywords: Olea europaea; biocontrol agents; Trichoderma; secondary metabolites; harzianic acid; 6-pentyl- $\alpha$-pyrone; volatile organic compounds; plant metabolic pathways; GC-MS analysis; Radiello ${ }^{\circledR}$ 


\section{Introduction}

Synthetic pesticides are employed in agriculture to control pests, avoid crop yield losses and product damage. Pesticides may negatively affect human health due to high biological activity and long persistence in the environment [1]. Pesticides in food products and drinking water determine a threat to human health [2]. They accumulate in living species and determine long-term and chronic effects [2]. Fungal biocontrol agents (BCAs) are a natural alternative to control plant diseases, and their complex modes of action generally does not induce resistance in insects, weeds, pests, and pathogens [3]. Microbes of the genus Trichoderma are the most studied and marketed fungal BCAs used as active ingredients of various bioformulations in agriculture [4]. They exert a direct activity against pathogens using different mechanisms: antibiosis, parasitism, and competition for nutrients and space [5]. Trichoderma spp. have shown rhizosphere competence, may improve plant health and growth, enhance nutrient availability and uptake, induce host resistance, and modify the plant metabolome [6,7]. These positive effects are associated with the production of effector metabolites that selected Trichoderma strains can release during the multicomponent interactions with the plant, pathogen, and other microbes [8,9]. For example, Trichoderma determines host-induced plant volatile alteration after root colonization in response to the inoculation of different microbial symbioses [10].

Plant volatile organic compounds (VOCs) may act as direct and indirect protective compounds [11-13]. They induce metabolomic, transcriptomic, and behavioral responses in receiver organisms, including insect pollinators and herbivores. The composition and concentration of VOCs may influence plant-insect and plant-plant interactions [14]. It is known that olive trees (Olea europaea L.) produce VOCs. Some VOCs were characterized in virgin olive oil and processed table olives; among these, C6 compounds, C9 aldehydes, hydrocarbons, and uncharacterized sesquiterpenes were found [15-19]. The olive tree diversifies volatile compounds' emission depending on the growth environmental conditions, e.g., the water status [20], and the season [21]. Moreover, previous studies showed that Trichoderma strains improved the nutraceutical properties of extra virgin olive oil and olive leaves [22-24]. Nevertheless, an extensive study on VOCs' modification in Trichoderma-treated olive plants and the possible correlations between the emissions of VOCs and physiological states or interactions with other organisms has not been reported so far. In this work, the effects of Trichoderma harzianum strains M10, T22, and TH1, T. asperellum strain KV906, T. virens strain GV41, or their metabolites harzianic acid (HA) and 6-pentyl- $\alpha$-pyrone (6PP), on the production of VOCs in olive trees were evaluated. The experiments were conducted in a controlled water regime, as previous studies showed that water availability affects the production of the alcohols, C6-saturated, and unsaturated aldehydes [25]. The VOCs production was monitored by Charcoal cartridge (Radiello ${ }^{\circledR}$ ) and analyzed by gas chromatography mass spectrometry (GC-MS). The effect of the treatments was evaluated by multivariate analysis to manage the variables and understand their relationships.

\section{Results}

\subsection{VOCs Identification}

In this study, olive trees were treated with Trichoderma spore suspensions (T. harzianum strains M10, TH1, T22; T. asperellum strain KV906, T. virens strain GV41) or their metabolite solutions (HA, 6PP) once per month from April to September. Radiello ${ }^{\circledR}$ technology was used to trap the VOCs produced by the plant during the experiments. After seven days of exposure, VOCs were chemically desorbed from the cartridges and analyzed by GC-MS allowing an excellent chromatographic separation. Blank samples were used to subtract noise interferences from sample chromatograms. Traces of benzene were found in blank samples (obtained using unexposed Radiello ${ }^{\circledR}$ samplers) due to its high solubility in carbon disulfide and its ability to be rapidly adsorbed on the activated carbon filter after exposure to the atmosphere. Three technical replicates were performed for each biological sample for a total of 120 GC-MS analyzes. The average of the three technical replicates was 
considered as the spectrum of the sample (See Supplementary Figure S1). The peaks were then automatically integrated.

The integration, when necessary, was manually corrected and the noise interferences found in blank samples were subtracted from each chromatogram. Forty-five major volatile compounds observed in total ion chromatograms (TICs) were identified by comparing their mass spectra with natural compounds present in database (Table 1).

Table 1. List of olive tree VOCs identified in this work. Radiello ${ }^{\circledR}$ technology was used to trap the VOCs during the experiments. After seven days of exposure, VOCs were chemically desorbed from the cartridges and analyzed by GC-MS. The asterisk $\left(^{*}\right)$ indicates air contaminants [26].

\begin{tabular}{|c|c|c|c|}
\hline N. & Compound Name & N. & Compound Name \\
\hline 1 & 1-Heptene, 2,6,6-trimethyl- & $24 *$ & Ethylbenzene \\
\hline 2 & 1-Hexanol, 5-methyl-2-(1-methylethyl)- & $25 *$ & Hexadecane \\
\hline 3 & 2,3-Dihydroxystearic acid & $26 *$ & Hexane, 3,3,4-trimethyl- \\
\hline & 3-Thiazolidinecarboxylic acid, & & \\
\hline 4 & $\begin{array}{l}\text { 4-(acetyloxy)-2-(1,1-dimethylethyl), } \\
\text { phenylmethyl ester, 1-oxide, [1R-(1. } \alpha ., 2 . \beta ., 4 . \beta)]\end{array}$ & 27 & Isobutyl 2-methylpentyl carbonate \\
\hline 5 & Acetic acid, butyl ester & 28 & Methylene chloride \\
\hline $6^{*}$ & Benzene & 29 & Nonane, 2,3-dimethyl- \\
\hline $7 *$ & Benzene, 1,2,4-trimethyl- & 30 & Nonane, 2,5-dimethyl- \\
\hline $8 *$ & Benzene, 1,3-bis(1,1-dimethylethyl)- & 31 & Nonane, 5-(2-methylpropyl)- \\
\hline $9 *$ & Benzene, 1,3-dimethyl- & $32 *$ & Octane, $1,1^{\prime}$-oxybis- \\
\hline 10 * & Benzene, 1-ethyl-4-methyl- & 33 * & Octane, 5-ethyl-2-methyl- \\
\hline 11 & $\begin{array}{l}\text { Butyronitrile, 2-(trimethylsilyloxy)-(3S)-(t- } \\
\text { butoxycarbonyl)amino- }\end{array}$ & $34 *$ & o-Xylene \\
\hline 12 & Cyclohexene, 1-methyl-4-(1-methylethenyl)-, (S)- & $35 *$ & p-Xylene \\
\hline 13 * & Cyclopentane, (2-methylpropyl)- & 36 & Sulfurous acid, butyl nonyl ester \\
\hline $14 *$ & Decane, 1-iodo- & 37 & Sulfurous acid, decyl hexyl ester \\
\hline $15^{*}$ & Decane, 2,3,5,8-tetramethyl- & $38 *$ & Tetrachloroethylene \\
\hline $16^{*}$ & Decane, 2-methyl- & 39 & Tetradecane \\
\hline 17 * & Decane, 3,7-dimethyl- & 40 & Tetradecane, 5-methyl- \\
\hline 18 * & Decane, 3,8-dimethyl- & $41 *$ & Toluene \\
\hline 19 * & Decane, 4-methyl- & 42 & trans-2,3-Epoxydecane \\
\hline $20 *$ & Decane, 5-methyl- & 43 * & Tridecane \\
\hline $21 *$ & Dodecane & $44^{*}$ & Undecane \\
\hline $22 *$ & Dodecane, 4,6-dimethyl- & 45 & Undecane, 6-ethyl- \\
\hline 23 & Ethanol, 1-(1-cyclohexenyl)- & & \\
\hline
\end{tabular}

The presence of specific olive tree VOCs was evaluated using single ion monitoring (SIM) analysis (Figure 1). Table 2 shows the nineteen volatile compounds emitted by the olive trees and the relative parameters used for their identification.

\subsection{VOCs Quantification}

The quantification of the VOCs was carried out by integrating the peak areas obtained from the gas chromatographic analysis. The method was validated in terms of linearity $\left(\mathrm{R}^{2} \approx 1\right)$, sensitivity (values were within the range established by the limits of detection and quantification), and repeatability (relative standard deviation, RSD, values $<15 \%$ confirmed the inter-and intraday repeatability). The parameters used to validate the quantification method have been reported as Supplementary Materials (Table S1). 
Table 2. List of specific olive tree volatile compounds found in this study and the parameters used for their identification.

\begin{tabular}{|c|c|c|c|c|c|c|}
\hline N. & Compound & Class & CAS Number & $\begin{array}{l}\text { SIM Signal } \\
\quad(a m u / z)\end{array}$ & Kovats Index & Ref. \\
\hline 1 & 1-Hexanol, 2-ethyl- & Alcohols & $104-76-7$ & 57 & 1030 & [27] \\
\hline 2 & Acetophenone & Aromatic ketones & $98-86-2$ & 105 & 1068 & [28] \\
\hline 3 & $\begin{array}{l}\text { Benzaldehyde,4- } \\
\text { methyl- }\end{array}$ & Aromatic aldehydes & $104-87-0$ & 119 & 1086 & [16] \\
\hline 4 & Benzyl alcohol & Alcohols & $100-51-6$ & 79 & 1040 & [27] \\
\hline 5 & Copaene & Sesquiterpenoids & $3856-25-5$ & 119 & 1375 & [28] \\
\hline 6 & $\begin{array}{c}\text { Cumyl alcohol } \\
\text { DMNT }\end{array}$ & Alcohols & $617-94-7$ & 121 & 1084 & [29] \\
\hline 7 & $\begin{array}{c}\text { [(E)-4,8-Dimethyl-1,3,7- } \\
\text { nonatriene }]\end{array}$ & Terpenoids & $51911-82-1$ & 69 & 1759 & [30] \\
\hline 8 & Funebrene & Terpenoids & 50894-66-1 & 119 & 1403 & [31] \\
\hline 9 & Isophorone & Cyclic ketones & 78-59-1 & 82 & 1123 & [32] \\
\hline 10 & Limonene & Monoterpenes & $138-86-3$ & 68 & 1030 & [28] \\
\hline 11 & Methyl benzoate & Benzoic acid esters & $93-58-3$ & 105 & 1096 & [28] \\
\hline 12 & Methyl salicylate & Benzoic acid esters & $119-36-8$ & 120 & 1192 & [28] \\
\hline 13 & Muurolene & Sesquiterpenoids & $10208-80-7$ & 105 & 1497 & [28] \\
\hline 14 & Myrcene & Monoterpenes & $123-35-3$ & 93 & 991 & [31] \\
\hline 15 & Nonanal & Aldehydes & $124-19-6$ & 57 & 1107 & [28] \\
\hline 16 & Nonane & Hydrocarbons & $111-84-2$ & 57 & 900 & [33] \\
\hline 17 & Phenol & Phenols & $108-95-2$ & 94 & 1011 & [27] \\
\hline 18 & Pinene & Monoterpenes & $2437-95-8$ & 93 & 943 & [34] \\
\hline 19 & $\mathrm{t}$-Ocimene & Monoterpenes & $13877-91-3$ & 93 & 976 & [30] \\
\hline
\end{tabular}

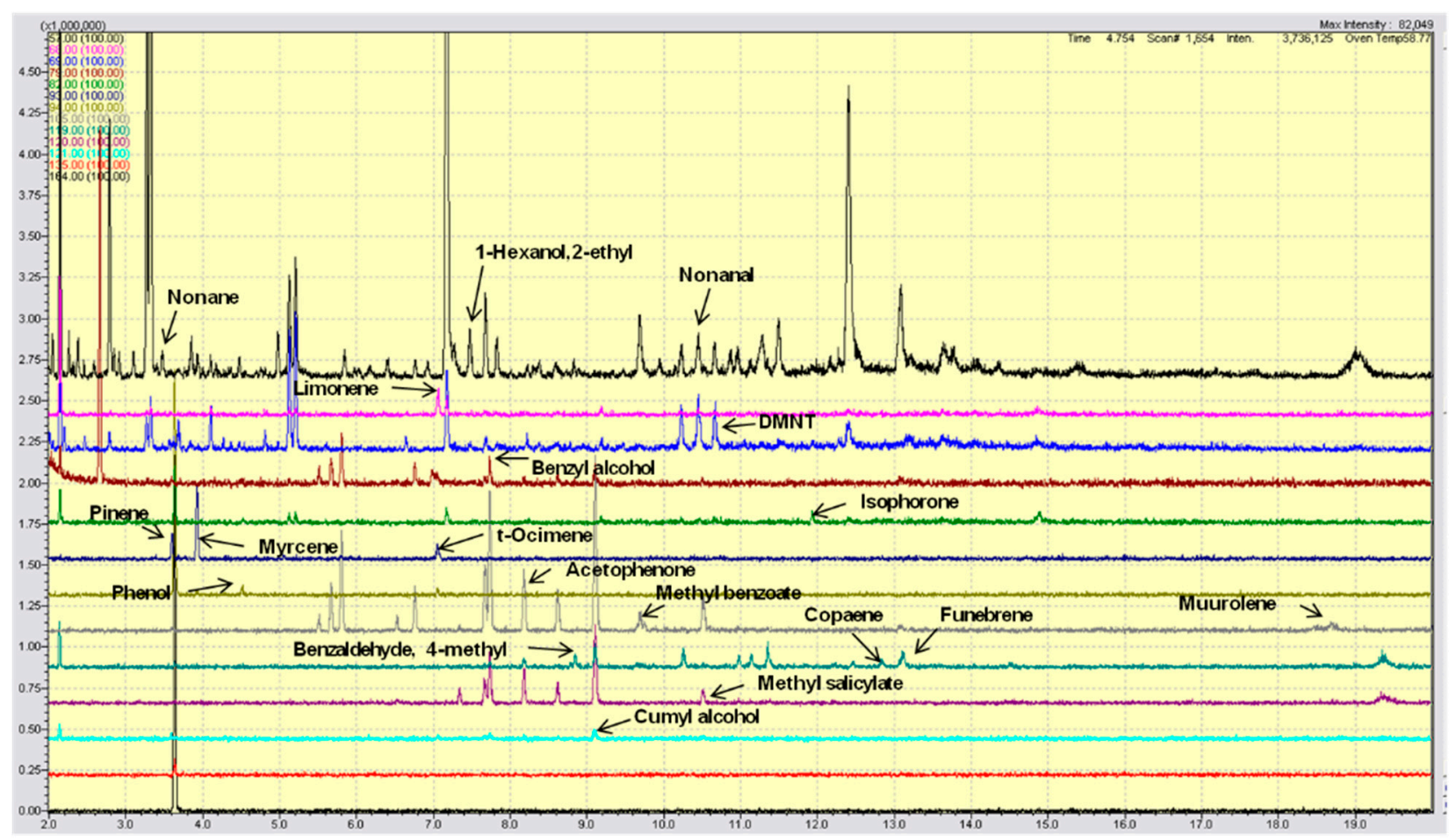

Figure 1. Gas chromatograms of specific olive tree VOCs evaluated using single ion monitoring (SIM) analysis. Different colors are used to better visualize the SIM signals of the VOC compounds (see Table 2), whose peaks are indicated by arrows.

In Table 3, the mean values of the VOCs produced by olive trees following the application of Trichoderma strains or metabolites have been reported. 
Table 3. Quantification of the VOCs produced by olive trees following the application of Trichoderma strains (M10, T22, TH1, KV906, GV41) or metabolites (HA, 6PP). Symbols in the tables indicate statistical differences among treatments as follows: * indicates a $p$-value $<0.05$ compared to CTRL; $\S$ indicates a $p$-value $<0.05$ compared to 6PP; $¥$ indicates a $p$-value $<0.05$ compared to GV41; II indicates a $p$-value $<0.05$ compared to M10; \& indicates a $p$-value $<0.05$ compared to T22; \% indicates a $p$-value $<0.05$ compared to TH1; $€$ indicates a $p$-value $<0.05$ compared to KV906; @ indicates a $p$-value $<0.05$ compared to HA. Each symbol has been also repeated under the treatment of reference in the first line of the Table.

\begin{tabular}{|c|c|c|c|c|c|c|c|c|}
\hline $\begin{array}{c}\text { VOC } \\
\text { ( } p \text {-Value) }\end{array}$ & CTRL * & M10 & T22 \& & TH1 \% & KV906 $£$ & GV41 $¥$ & HA @ & $6 P P \S$ \\
\hline $\begin{array}{c}\text { 1-Hexanol, } \\
\text { 2-Ethyl- } \\
(0.0013527) \\
\end{array}$ & $18.35 \pm 4.29$ & $16.03 \pm 4.59$ & $\underset{\substack{10.66 \pm 0 \\
\S * \mathbb{I}}}{0.18}$ & $\begin{array}{c}11.00 \pm 0.75 \\
\S^{*} ¥ \mathbb{I}\end{array}$ & $\underset{\S^{*} \mathbb{I}}{11.42 \pm 0.30}$ & $15.45 \pm 4.95$ & $10.58 \pm 0.47$ & $15.70 \pm 4.25$ \\
\hline $\begin{array}{l}\text { Acetophenone } \\
\left(5.03 \times 10^{-1}\right)\end{array}$ & $\underset{\S \neq}{11.88 \pm 0} 0.99$ & $11.53 \underset{\S \nsubseteq}{ \pm} 1.03$ & $\begin{array}{c}12.00 \pm 0.52 \\
\S 尹\end{array}$ & $\begin{array}{c}11.32 \pm 0.62 \\
\S \neq\end{array}$ & $\underset{\S \nsubseteq 11.06 \pm 0.42}{\$ \nsubseteq}$ & $13.14 \pm 0.87$ & $\begin{array}{c}11.40 \pm 0.24 \\
\S ¥\end{array}$ & $13.47 \pm 0.88$ \\
\hline $\begin{array}{l}\text { Benzaldehyde, } \\
\text { 4-Methyl } \\
\left(1.11 \times 10^{-2}\right)\end{array}$ & $\underset{\S \nsubseteq}{2.96 \pm 0.49}$ & $\begin{array}{c}3.17 \pm 0.36 \\
\S \&\end{array}$ & $\begin{array}{c}2.70 \pm 0.18 \\
\S ¥ \mathbb{I}\end{array}$ & $\begin{array}{c}2.90 \pm 0.20 \\
\S ¥ \&\end{array}$ & $\begin{array}{l}2.46 \pm 0.33 \\
\text { *§¥II\& }\end{array}$ & $\begin{array}{c}3.42 \pm 0.37 \\
\text { *\&£\& }\end{array}$ & $\underset{\S \&}{3.08 \pm 0.06}$ & $\begin{array}{c}3.93 \pm 0.32 \\
{ }^{*} £^{\circ} \%\end{array}$ \\
\hline $\begin{array}{c}\text { Benzyl } \\
\text { alcohol } \\
\left(1.51 \times 10^{-5}\right) \\
\end{array}$ & $\begin{array}{c}3.68 \underset{\S \&}{ \pm} 0.16 \\
\qquad \&\end{array}$ & $\begin{array}{c}3.17 \pm 0.10 \\
\text { *§抽\& }\end{array}$ & $4.32 \pm 0.40$ * & $\begin{array}{c}3.13 \pm 0.24 \\
\text { *¥¥@\& }\end{array}$ & $\begin{array}{c}3.21 \pm 0.16 \\
* \S ¥ \&\end{array}$ & $4.35 \pm 0.44$ * & $3.53 \underset{\S ¥}{ \pm} 0.31$ & $4.18 \pm 0.19^{*}$ \\
\hline $\begin{array}{c}\text { Copaene } \\
(0.031723) \\
\end{array}$ & $2.35 \pm 0.62 *$ & $2.19 \pm 0.69$ & $\begin{array}{c}1.71 \underset{\$ \nsubseteq}{ \pm} 0.03 \\
\end{array}$ & $1.77 \underset{\S^{*}}{ \pm} 0.16$ & $1.88 \pm 0.18 \S$ & $2.25 \pm 0.32$ & $2.06 \pm 0.17$ & $2.46 \pm 0.34$ \\
\hline $\begin{array}{c}\text { Cumyl } \\
\text { alcohol } \\
(0.00047929) \\
\end{array}$ & $\begin{array}{c}1.60 \pm 0.28 \\
\S \&\end{array}$ & $1.79 \pm 0.27$ & $1.91 \pm 0.18$ & $\begin{array}{c}1.38 \pm 0.03 \\
\S ¥ £ \mathbb{I} \&\end{array}$ & $1.73 \pm 0.16$ & $1.85 \pm 0.22 \%$ & $\begin{array}{c}1.42 \pm 0.20 \\
\S ¥ £ \llbracket \&\end{array}$ & $1.92 \pm 0.23$ \\
\hline $\begin{array}{c}\text { DMNT } \\
(0.00010625) \\
\end{array}$ & $\begin{array}{c}7.00 \pm 4.43 \\
£ \& \%\end{array}$ & $\begin{array}{c}7.18 \pm 4.78 \\
£ \& \%\end{array}$ & $11.10 \pm 0.64$ & $12.53 \pm 0.81$ & $14.14 \pm 0.47$ & $\begin{array}{c}6.12 \pm 3.99 \\
@ £ \& \%\end{array}$ & $10.50 \pm 0.23$ & $\begin{array}{c}4.95 \pm 3.19 \\
@ £ \%\end{array}$ \\
\hline $\begin{array}{c}\text { Funebrene } \\
\left(3.14 \times 10^{-2}\right)\end{array}$ & $\begin{array}{c}6.68 \pm 1.48 \\
\text { II\&\%£@§ }\end{array}$ & $\begin{array}{l}5.46 \pm 1.22 \\
\& \% £ ¥ @\end{array}$ & 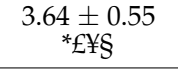 & $3.82 \pm 0.09 *$ & $\begin{array}{c}2.79 \pm 0.10 \\
* \mathbb{I} ¥ \S \\
\end{array}$ & $\begin{array}{c}6.08 \pm 1.68 \\
\quad \& \% @\end{array}$ & 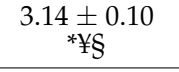 & $\begin{array}{l}5.08 \pm 1.44 \\
* \& £ @\end{array}$ \\
\hline $\begin{array}{c}\text { Isophorone } \\
\left(2.35 \times 10^{-2}\right)\end{array}$ & $\begin{array}{c}2.16 \pm 0.28 \\
@ \S \S\end{array}$ & $\begin{array}{c}2.46 \pm 0.20 \\
\&\end{array}$ & $\begin{array}{c}1.98 \pm 0.14 \\
\mathbb{I} \%\end{array}$ & $2.56 \pm 0.29 \&$ & $2.19 \pm 0.64$ & $\begin{array}{c}2.12 \pm 0.51 \\
@ \S \S\end{array}$ & $\begin{array}{l}2.66 \pm 0.21 \\
* \& £ ¥ \S\end{array}$ & 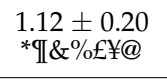 \\
\hline $\begin{array}{c}\text { Limonene } \\
\left(3.93 \times 10^{-2}\right)\end{array}$ & $\begin{array}{c}3.30 \pm 0.75 \\
\mathbb{I} \& \% ¥ @ \S \\
\end{array}$ & $5.45 \underset{{ }^{ \pm}}{ \pm} 0.76$ & $\begin{array}{c}5.00 \pm 0.27 \\
\text { *£@§ }\end{array}$ & $\begin{array}{c}4.56 \pm 0.16 \\
* @ \S \\
\end{array}$ & $\begin{array}{c}3.64 \pm 0.15 \\
\text { II\&@§ }\end{array}$ & $\begin{array}{c}4.43 \pm 1.42 \\
* @ \S \\
\end{array}$ & $\begin{array}{c}6.42 \pm 1.56 \\
* \& \% £ ¥ \\
\end{array}$ & $\begin{array}{c}6.32 \pm 0.22 \\
* \& \% £ ¥\end{array}$ \\
\hline $\begin{array}{c}\text { Methyl } \\
\text { benzoate } \\
\left(3.54 \times 10^{-3}\right) \\
\end{array}$ & $\begin{array}{c}5.10 \pm 0.98 \\
\% ¥ \S\end{array}$ & $4.57 \pm 0.85 \S$ & $4.39 \pm 0.13 \S$ & $\begin{array}{c}4.16 \pm 0.17 \\
* \& \S\end{array}$ & $4.43 \pm 0.68 ¥ \S$ & $\begin{array}{l}6.20 \pm 0.87 \\
* \mathbb{I} \& \% £ @\end{array}$ & $4.89 \underset{¥ \S}{ \pm} 0.37$ & $\begin{array}{l}6.80 \pm 0.21 \\
* \mathbb{I} \& \% £ @\end{array}$ \\
\hline $\begin{array}{c}\text { Methyl } \\
\text { salicylate } \\
(0.00071484) \\
\end{array}$ & $2.58 \underset{¥ \S}{ \pm} 0.36$ & $2.37 \underset{¥ \S}{ \pm} 0.25$ & $2.47 \underset{¥ \S}{ \pm} 0.26$ & $2.68 \underset{¥ \S}{ \pm} 0.05$ & $2.70 \underset{¥ \S}{ \pm} 0.12$ & $\begin{array}{c}3.17 \pm 0.31 \\
* \mathbb{I I E @ ~}\end{array}$ & $2.72 \pm 0.48 ¥$ & $\begin{array}{l}3.06 \pm 0.06 \\
* \mathbb{I} \& \% £\end{array}$ \\
\hline $\begin{array}{c}\text { Muurolene } \\
\left(3.98 \times 10^{-1}\right) \\
\end{array}$ & $\begin{array}{c}3.09 \pm 0.72 \\
\& \% \nsubseteq ¥ @\end{array}$ & $\begin{array}{c}3.17 \pm 1.65 \\
\& \% \nsubseteq ¥ @\end{array}$ & 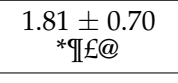 & $\begin{array}{c}1.54 \pm 0.64 \\
* \mathbb{I I \& E}\end{array}$ & $\begin{array}{c}0.32 \pm 0.06 \\
* \mathbb{I} \& \% \S \\
\end{array}$ & $1.40 \underset{* \mathbb{*}}{ \pm} 0.74$ & $\begin{array}{c}0.66 \pm 0.31 \\
* \mathbb{I I \& \$}\end{array}$ & $\begin{array}{c}2.17 \pm 1.09 \\
£ @\end{array}$ \\
\hline $\begin{array}{c}\text { Myrcene } \\
(0.00088287) \\
\end{array}$ & $\begin{array}{c}11.66 \pm 1.23 \\
¥ \S\end{array}$ & $\begin{array}{c}12.14 \pm 1.64 \\
@\end{array}$ & $11.48 \underset{\neq}{ \pm} 0.65$ & $\begin{array}{c}10.42 \pm 0.42 \\
\mathbb{I I ¥}\end{array}$ & $11.41 \underset{¥}{ \pm} 0.42$ & $\begin{array}{c}13.22 \pm 1.75 \\
* \& \% £ @ \S\end{array}$ & $\begin{array}{c}10.70 \pm 0.43 \\
\mathbb{I} ¥ \S \\
\end{array}$ & $\begin{array}{c}13.02 \pm 0.31 \\
\text { *\&ะ@@ }\end{array}$ \\
\hline $\begin{array}{c}\text { Nonanal } \\
\left(1.39 \times 10^{-1}\right)\end{array}$ & $\begin{array}{l}9.20 \pm 5.59 \\
\& \% £ @\end{array}$ & $\begin{array}{l}8.67 \pm 5.27 \\
\& \% £ @\end{array}$ & $\begin{array}{c}14.30 \pm 1.90 \\
* \mathbb{I} ¥ \S\end{array}$ & $\begin{array}{c}16.44 \pm 1.02 \\
* \text { ॠIS } \\
\end{array}$ & $\begin{array}{c}17.15 \pm 0.37 \\
* \llbracket \mathbb{I} § \\
\end{array}$ & $\begin{array}{l}8.57 \pm 4.88 \\
\& \% £ @\end{array}$ & 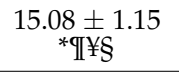 & $\begin{array}{c}5.33 \pm 2.98 \\
\& \% £ @\end{array}$ \\
\hline $\begin{array}{c}\text { Nonane } \\
\left(7.07 \times 10^{-2}\right) \\
\end{array}$ & $3.43 \pm 0.58$ & $\begin{array}{c}2.91 \pm 0.65 \\
@ \%\end{array}$ & $\begin{array}{c}3.57 \pm 0.06 \\
¥ £ \%\end{array}$ & $\begin{array}{c}4.84 \pm 0.57 \\
\quad * \S \neq \\
\end{array}$ & 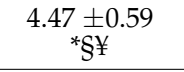 & $2.63 \pm 1.01 @$ & $4.37 \pm 0.46$ *§ & $2.75 \pm 0.83$ \\
\hline $\begin{array}{c}\text { Phenol } \\
\left(2.01 \times 10^{-4}\right) \\
\end{array}$ & $1.10 \pm 0.11$ & $\begin{array}{c}1.59 \pm 0.17 \\
\S^{*} ¥ @ 0\end{array}$ & $\begin{array}{c}1.22 \pm 0.02 \\
¥ @ \mathbb{1} \\
\end{array}$ & $\begin{array}{c}0.65 \pm 0.02 \\
\S^{*} ¥ @ \& \&\end{array}$ & $\begin{array}{c}0.83 \pm 0.24 \\
\mathcal{S}^{*} \mathbb{I} \&\end{array}$ & $0.96 \pm 0.16$ & $0.99 \pm 0.24$ & $1.08 \pm 0.17$ \\
\hline $\begin{array}{c}\text { Pinene } \\
\left(1.28 \times 10^{-6}\right)\end{array}$ & $3.03 \pm 0.44 \S$ & $\begin{array}{c}3.78 \pm 0.22 \\
\quad ¥ @ £ \% \\
\end{array}$ & $\begin{array}{l}3.79 \pm 0.16 \\
\quad ¥ @ £ \% \\
\end{array}$ & $2.83 \underset{\S £}{ \pm} 0.20$ & $\begin{array}{c}3.51 \pm 0.19 \\
\S^{*} ¥ 0\end{array}$ & $2.93 \pm 0.11 \S$ & $2.91 \pm 0.06 \S$ & $3.88 \pm 0.06$ \\
\hline $\begin{array}{c}\mathrm{t} \text {-Ocimene } \\
\left(1.13 \times 10^{-2}\right)\end{array}$ & $1.94 \pm 0.10 \S$ & $\begin{array}{c}3.51 \pm 0.76 \\
\S^{*} £\end{array}$ & $\begin{array}{c}3.16 \pm 0.19 \\
\S^{* @ £} \\
\end{array}$ & 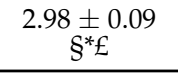 & $\begin{array}{c}1.97 \pm 0.09 \\
\S @\end{array}$ & $\begin{array}{c}2.86 \pm 0.85 \\
\S^{* @ £} \\
\end{array}$ & $4.02 \pm 1.21 *$ & $4.29 \pm 0.13$ \\
\hline
\end{tabular}

\subsection{Correlation between Emission of VOCs and Trichoderma Applications}

Replicate samples were grouped according to the abundance of continuous variables in a hierarchical cluster analysis (one-way ANOVA, $p<0.05$ ). Figure 2 reports the heat map obtained analyzing the 19 volatile compounds that differentially accumulated among treatments and comparing their chemical abundance vs. control (water-treated plants). Interestingly, all the detected VOCs were significantly affected by the treatments with Trichoderma strains or metabolites. Overall, we found that among treated plants, those inoculated with Trichoderma strain KV906, HA or 6PP showed a higher number of differential 
VOCs with lower chemical abundance (blue color), while a higher number of differential compounds with higher chemical abundance (red color) were observed in the control, M10-, GV41-, or TH1-treated plants (Figure 2).

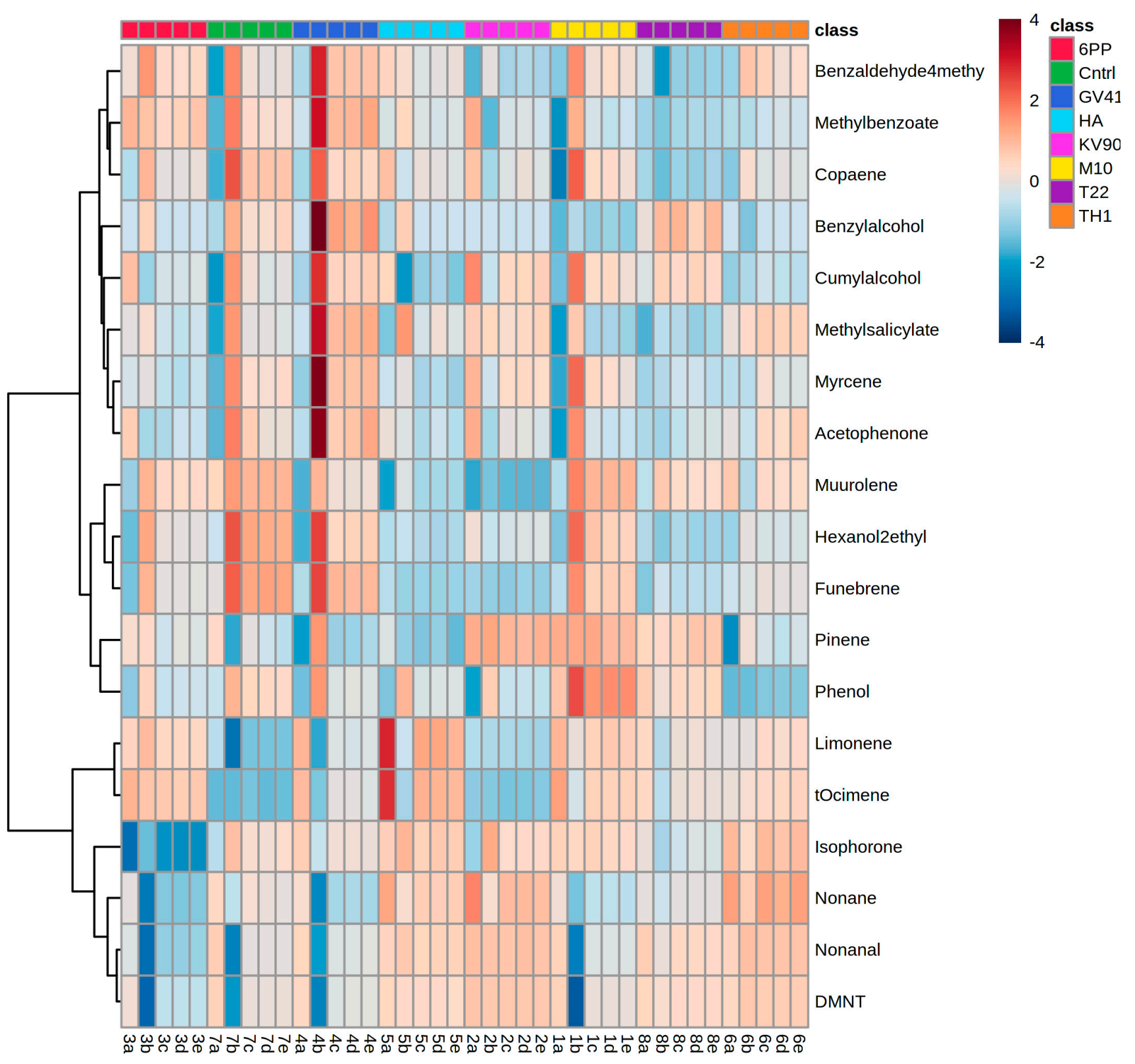

Figure 2. Hierarchical clustering heat map of differential volatile compounds produced by olive trees. Each column represents the samples obtained by plants treated with Trichoderma spores (M10, TH1, T22, KV906, and GV41,) or metabolites (6PP and HA). Water-treated plants served as controls (CTRL). In the heat map, red and blue colors indicate higher and lower chemical abundance, respectively. Treatments are indicated according to the color scale (class) shown in the legend at the top right. Data are presented as individual values from each biological replication. Statistical differences were determined using one-way ANOVA $(p<0.05)$.

\section{Discussion}

In this study olive trees were treated with Trichoderma spore suspensions or their metabolite solutions, and Radiello ${ }^{\circledR}$ technology was used to trap the VOCs $[35,36]$. Fortyfive volatile compounds were detected and identified by GC-MS. These included hydrocarbons (e.g., decane, octane, nonane, etc.) and aromatics (e.g., benzene and deriva- 
tives). The most abundant VOCs were benzene, dodecane, toluene, and tetradecane. These compounds are contaminants generally present in the air [26]. Volatile compounds specifically emitted by the olive tree leaves and fruits were obtained by subtracting the contaminants present in the blank sample and comparing the data with the existing literature $[27-34,37,38]$. VOCs related to the field treatment with biocontrol agents were selected using a targeted metabolomics approach and comparing treated plants with controls. The target VOCs analyses were obtained by extracting the Single Ion Monitoring (SIM) signals from the gas chromatograms acquired in Full Scan function between 40 and $500 \mathrm{amu} / \mathrm{z}$. Nineteen compounds, including terpenes, ketones, aldehydes, and aromatic compounds were emitted by plants in response to field treatments with Trichoderma spore suspensions or metabolite solutions [39]. Statistical analyses were performed to evaluate the effects of each treatment on the emission of VOCs by olive trees. A hierarchical clustering heat map of differential volatile compounds produced by olive trees was used to understand the optimal method for scaling the data (Figure 2). The search for the selected target VOCs showed a distribution strongly influenced by the treatments. Interestingly, terpenes release was strongly influenced by olive trees' treatment with strain M10 or the metabolites 6PP and HA. The emission of aromatic compounds was influenced by the application of Trichoderma strains T22, TH1, M10, and GV41 or the metabolites (6PP and HA). The emission of aldehydes was mainly affected by strains GV41 and KV906, or the compound HA.

In the plant cells, the terpenoids' biosynthesis occurs in the plastids and cytosol (Figure 3). In the plastids, the GDP (prenyl diphosphates geranyl diphosphate) influences the monoterpenes' synthesis, and the GGDP (geranylgeranyl diphosphate) controls that of the diterpenes. In the cytosol, sesquiterpene biosynthesis occurs using farnesyl diphosphate (FDP) [40]. As already seen in our previous work, these results confirmed Trichoderma ability to interfere with the geranyl diphosphate in the biosynthetic pathway [22]. The concentration of myrcene, pinene, and DMNT did not increase after Trichoderma treatments. These data can be explained considering that such volatiles are monoterpenes modified into limonene and/or other oxidized metabolites before the plant's emission. No significant interferences were found with the biosynthesis of sesquiterpenes (copaene, funebrene, and muurolene). Limonene (4-isopropenyl-1-methylcyclohexene) has an important ecological role in plants [41], working as an attractant for pollinators, as part of a defense mechanism, an antifeedant, and an antifungal compound [42]. It is toxic for some herbivore species [43] and is an allelopathic agent in hot and dry climates [44]. Moreover, limonene has chemopreventive, antitumoral [45], hypoglycemic [46], antioxidant [47,48] anti-inflammatory [46], antibacterial [49], and antifungal [50] properties.

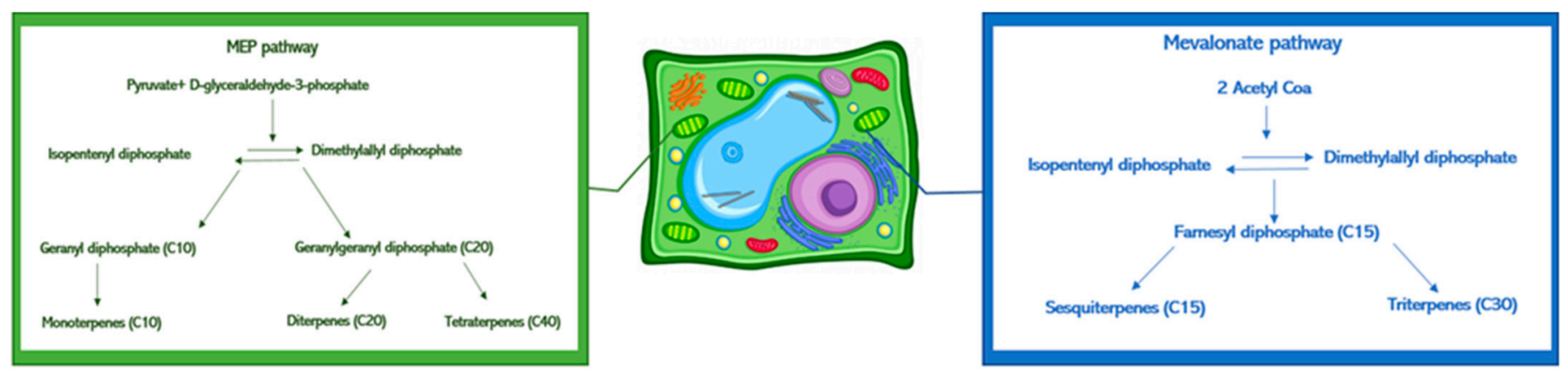

Figure 3. Schematic representation of terpenes biosynthetic pathways in the plant cell.

Elevated levels of nonanal observed in treated plants indicate that biostimulants might modulate the lipid-signaling pathways controlling the enzyme lipoxygenase (LOX). Alkenes and ketones volatile compounds containing C6 to C16 chain are generally the result of fatty acid metabolism [48], while C9-compounds derivate from the oxidation of linoleic and linolenic acid [51,52]. In the lipid-signaling pathway, decarboxylation 
yields alkanes, methyl ketones, or 1-alkenes, and the carboxy group reduction produces 1-alkanols and aldehydes. Nonanal inhibits Penicillium cyclopium and Botrytis cinerea's mycelial growth by disrupting the fungal cell membrane's integrity, leaking the cell constituents and potassium ions, enhancing the extracellular $\mathrm{pH}$, the total lipid content, and the membrane permeability [53,54]. Moreover, the nonanal acts as an attractant for pollinators [55], is an antifeedant [56], and controls, via the activation of peripheral neurons (e.g., in Helicoverpa assulta), the insect oviposition preference [57]. Finally, nonanal has anti-diarrheal properties on humans [58]. The elevated value of methyl salicylate emitted when Trichoderma strains GV41, KV906, and TH1, or the metabolites HA and 6PP were used in the field showed that they were able to interfere with the shikimic acid pathway according to previous work [24]. Similarly, it is possible to explain the positive effect of benzyl alcohol release into the environment when Trichoderma strains GV41 and M10, and the metabolite 6PP were used in the field (Figure 4) [59].

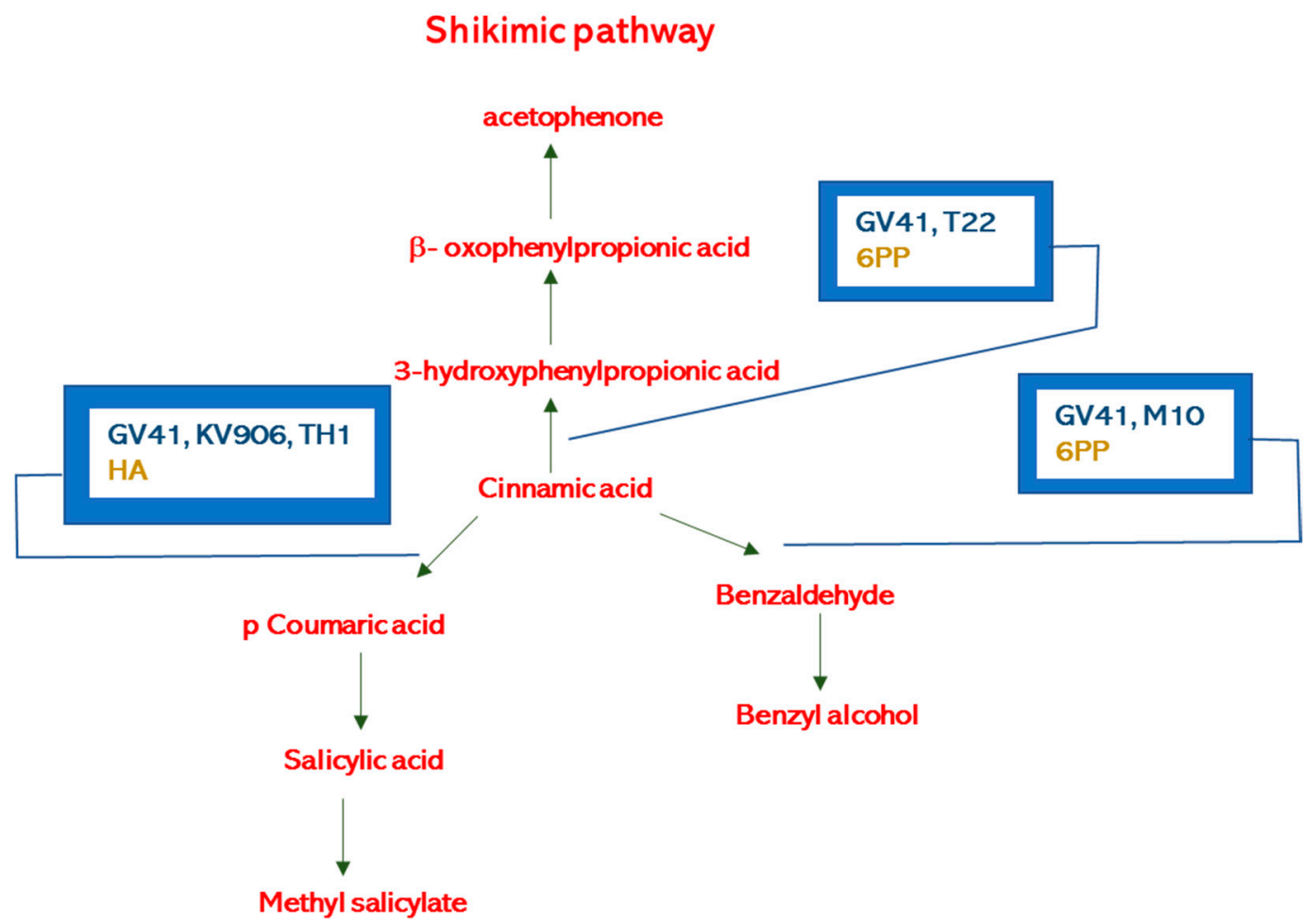

Figure 4. Benzene derivatives biosynthetic pathways and possible influence of Trichoderma strains (GV41, T22, M10, KV906, TH1) or metabolites (HA, 6PP).

\section{Materials and Methods}

\subsection{Fungal Strains and Microbial Metabolites}

T. harzianum strains M10, T22, and TH1, T. asperellum strain KV906, T. virens strain GV41 were cultivated as previously described [24]. Fungal spores were collected and maintained at $-20{ }^{\circ} \mathrm{C}$ in $20 \%$ glycerol before use. Spore concentrations were determined by using a hemocytometer. In this work, the Trichoderma secondary metabolites harzianic acid (HA) and 6-pentyl- $\alpha$-pyrone (6PP) were isolated from Trichoderma culture filtrate as previously reported [60-62].

Fungal metabolites were solubilized in water under continuous stirring overnight.

\subsection{Plant Material and Experimental Setup}

Experiments were conducted on two-years-old olive trees (Olea europaea L.) cv. Carolea, a typical south Italian variety. The plants were transplanted into pots and placed in a field trial at the Department of Agricultural Sciences at the University of Naples Federico II 
(Portici, Naples, Italy). The experiments consisted of 8 treatments, including water control, T. harzianum strains M10, T22, and TH1, T. asperellum strain KV906, T. virens strain GV41, and their secondary metabolites harzianic acid (HA), and 6-pentyl- $\alpha$-pyrone (6PP). The field trial was arranged in a completely randomized block design with a $1.30 \mathrm{~m}$ distance between the plants (see Supplementary Figure S2). Cultivar Pendolino was used as a pollinating plant and distributed in the field trial. Olive trees were treated with Trichoderma spore suspensions $\left(1 \times 10^{7} \mathrm{sp} / \mathrm{mL}\right)$ or fungal metabolite solutions $\left(1 \times 10^{-5} \mathrm{M}\right)$ at the time of transplant by root dip ( $10 \mathrm{~min}, 1 \mathrm{~L} /$ plant), and repeated every 30 days by soil drenching (400 mL/plant), for a total of 6 applications. Each treatment was applied to five plants with three biological replicates, for a total of 15 plants per treatment.

\subsection{Collection of VOCs}

Charcoal cartridges (Radiello ${ }^{\circledR} 130$, Supelco, St. Louis, MO, USA) were used to adsorb the olive trees' VOCs. The cartridge's adsorbing capacity was about $80 \mathrm{mg}$, equivalent to exposure to total VOCs of $3000-3500 \mathrm{mg} / \mathrm{m}^{3}$ for $8 \mathrm{~h}$ or $70,000-80,000 \mu \mathrm{g} / \mathrm{m}^{3}$ for 14 days. The analytical performances of Radiello ${ }^{\circledR}$ were validated by Supelco and reported in the instruction manual. The Radiello ${ }^{\circledR}$ cartridges were placed in the upper part of the olive tree, near the plant's stem and in a direction parallel to it (see Supplementary Figure S3). All cartridges were set at the same height and were removed on the same day. Five replicates were used per each treatment.

The samples were stored at $-20^{\circ} \mathrm{C}$ until analysis. The cartridges were analyzed within a week. VOCs were extracted with $2 \mathrm{~mL}$ of carbon disulfide $\left(\mathrm{CS}_{2}\right)$ in chlorobenzene $(100 \mu \mathrm{g} / \mathrm{L})$ directly in the Radiello ${ }^{\circledR}$ glass storage tube without drawing out the cartridge. $\mathrm{CS}_{2}$ served as an internal standard. The same extraction was carried out on a new unexposed cartridge used as blank. Blank samples were used to subtract noise interferences from sample chromatograms.

\subsection{GC-MS Analysis}

After $30 \mathrm{~min}$, the $\mathrm{CS}_{2}$ solution $(1 \mu \mathrm{L})$ was injected in a GC-MS-QP2010 instrument (Shimadzu Corp., Kyoto, Japan) consisting of a GC-2010 Plus gas chromatograph coupled to a 2010 Plus single quadrupole mass spectrometer. Separations were performed using a $30 \mathrm{~m}$ column (JB DB-WAX, $0.25 \mathrm{~mm}$ id, $0.25 \mu \mathrm{m}$ film thickness, Agilent Technologies, Santa Clara, CA, USA), with helium as carrier gas. The initial oven temperature of $40^{\circ} \mathrm{C}$ was held for $1 \mathrm{~min}$ and then raised to $120^{\circ} \mathrm{C}$ at a rate of $5^{\circ} \mathrm{C} / \mathrm{min}$, with a further $3 \mathrm{~min}$ of hold time. The gas flow was set to achieve a constant linear velocity of $45 \mathrm{~cm} / \mathrm{s}$, and the split ratio was set to 10:1. The total run time was $20 \mathrm{~min}$, and the injection temperature was set at $200{ }^{\circ} \mathrm{C}$. The mass spectrometer operated in electron impact $(70 \mathrm{eV})$ in full scan mode in the interval of $40-500 \mathrm{~m} / \mathrm{z}$ with a scan velocity of $5000 \mathrm{amu} / \mathrm{s}$ and a solvent cut time of $1.9 \mathrm{~min}$. The ion source temperature was set at $200^{\circ} \mathrm{C}$, and the interface temperature at $180^{\circ} \mathrm{C}$. Each biological replicate was run in triplicate (technical replicates) for 120 GC-MS separations. Before the analysis, a solvent blank was analyzed (pure $\mathrm{CS}_{2}$ solution), and then an analytical blank was obtained by extracting an unexposed cartridge with $2 \mathrm{~mL}$ of $\mathrm{CS}_{2}$ solution. Peak areas were automatically normalized to the standard internal area, and metabolite identification was performed by comparing each peak's mass spectrum with the NIST library collection (NIST, Gaithersburg, MD, USA). The linear index difference max tolerance was set at 10, while the minimum matching for the NIST library search was set at $85 \%$. Using the Kovats index, identification was further confirmed by analyzing a series of hydrocarbons (C10-C26).

Method validation. Calibration curves were built by using external standards. From each curve, it was possible to obtain the linearity (from the regression coefficient), the limit of detection (LODs $\left.=3 \times \frac{\text { standard deviation }}{\text { angular coef ficient }}\right)$, and quantification (LOQs $=10 \times \frac{\text { standard deviation }}{\text { angular coefficient }}$ ). Intraday repeatability was tested by injecting eight different concentrations of each standard three times. The interday variations were found carrying out after seven days of the same 
experiments. Standards were purchased by Sigma-Aldrich (St. Louis, MO, USA) except Muurolene (Molbase Biotechnology Co., Ltd. Shanghai, China).

\subsection{Statistical Analysis}

Results were summarized in a comma-separated matrix (CSV) file and loaded in the appropriate statistics manipulation software. The normalization procedures consisted of data transformation and scaling. Data transformation was made by generalized log transformation and data scaling by autoscaling (mean-centered and divided by each variable's standard deviation) [63]. The chromatographic data were tabulated with one sample per row and one variable (metabolite) per column. Statistical analysis was performed using Statistica software (StatSoft, Tulsa, OK, USA) and Minitab (Minitab Inc., State College, PA, USA). Fisher's least significant difference (LSD) post hoc test at the 0.05 level of significance was used.

Clustering analysis. Metabolite expression ratios of VOCs (column) were log2 transformed and normalized using $z$-scores. In the vertical heat map, colour coding indicated concentration differences for each metabolite (row): z-scores $>0$ (red), $<0$ (blue) and $\approx 0$ (white).

\section{Conclusions}

This study allowed the analysis of the volatile organic substances emitted by olive trees under treatment with formulations based on different strains belonging to the genus Trichoderma or metabolites extracted from them. Forty-five compounds have been identified by gas chromatography, of which nineteen compounds were imputable to olive trees emissions. Statistical analysis showed that each treatment influenced the different VOCs ${ }^{\prime}$ relative concentrations, allowing to obtain a characteristic profile of compounds released by the olive tree treated with Trichoderma living fungus or its metabolites. For these compounds each treatment's relative concentrations were explored to allow a quick and visual interpretation of the results obtained. Considering relevant metabolic pathways acting on VOCs' formation after treatments, we found a significant effect on three biosynthetic pathways: methylerythritol 1-phosphate (MEP) pathway (by Trichoderma strain M10, and metabolites 6PP and HA), lipid-signaling pathway (by Trichoderma strains GV41, KV906 and the metabolite HA) and shikimate pathway (by Trichoderma strains GV41, M10, T22, TH1, and the metabolites HA and 6PP) (Table 4).

Table 4. Olive VOC biosynthetic pathways possibly affected by Trichoderma applications (strains or metabolite).

\begin{tabular}{ccc}
\hline Trichoderma & Metabolic Pathway & Class of VOCs \\
\hline Strain GV41 & Shikimate pathway & Aromatics \\
Strain KV906 & Lipid-signaling pathway & Aldehydes \\
Strain M10 & Lipid-signaling pathway & Aldehydes \\
Strain T22 & MEP pathway & Terpenes \\
Strain TH1 & Shikimate pathway & Aromatics \\
& Shikimate pathway & Aromatics \\
Metabolite HA & Shikimate pathway & Aromatics \\
& MEP pathway & Terpenes \\
Metabolite 6PP & Shikimate pathway & Aromatics \\
& Lipid-signaling pathway & Aldehydes \\
\end{tabular}

Considering that the different volatile compounds have different activities and roles in the ecosystems, our work provides essential information on olive tree/Trichoderma interaction. This interaction positively interferes with VOCs' biosynthesis, confirming the beneficial effects of these microbes on plants. 
Supplementary Materials: The following are available online at https:/ / www.mdpi.com/article/10 $.3390 /$ metabo11040213/s1, Table S1: Parameters used to validate the relative-quantification method of the VOCs produced by olive trees following the application of Trichoderma strains or metabolites, Figure S1: Example of an integrated gas chromatogram resulting from the extraction of plant VOCs sampled by Radiello®cartridges, Figure S2: Randomized block design of field experiment, Figure S3: Application of the Radiello®cartridges to olive trees.

Author Contributions: Conceptualization, P.C. and F.V.; methodology, F.V., J.T. and G.S.; software, J.T.; formal analysis and writing-original draft preparation, I.D. and R.M.; data curation, A.P., I.S. and P.L.; writing-review and editing, I.D., R.M., P.C., J.T. and F.V.; project administration, I.D., R.M., P.C. and F.V.; funding acquisition, G.S. and F.V. All authors have read and agreed to the published version of the manuscript.

Funding: This research was funded by the following projects: MIURPON (grant number Linfa 03PE_00026_1; grant number Marea 03PE_00106); POR FESR CAMPANIA 2014/2020-O.S. 1.1 (grant number Bioagro CUP B63D18000270007); MISE (grant number Protection F/050421/01-03/X32); Regione Campania PSR 2014-2020 (grant number DIONISO B98H19005010009); Regione Veneto PSR 2014-2020 (grant number DIVINE 3589659).

Institutional Review Board Statement: Not applicable.

Informed Consent Statement: Not applicable.

Data Availability Statement: The data presented in this study are available on request from the corresponding author or the first author. The data are not publicly available due to privacy.

Acknowledgments: The authors R.M., A.P., P.L. and F.V. are grateful to Marica Pascale and Mauro Senatore for their helpful support in field experiments.

Conflicts of Interest: The authors declare no conflict of interest. The funders had no role in the design of the study; in the collection, analyses, or interpretation of data; in the writing of the manuscript, or in the decision to publish the results.

\section{References}

1. Bao, L.-J.; Wei, Y.-L.; Yao, Y.; Ruan, Q.-Q.; Zeng, E.Y. Global trends of research on emerging contaminants in the environment and humans: A literature assimilation. Environ. Sci. Poll. Res. 2015, 22, 1635-1643. [CrossRef]

2. Gavrilescu, M.; Demnerová, K.; Aamand, J.; Agathos, S.; Fava, F. Emerging pollutants in the environment: Present and future challenges in biomonitoring, ecological risks, and bioremediation. New Biotechnol. 2015, 32, 147-156. [CrossRef] [PubMed]

3. Savita, S.A. Fungi as biological control agents. In Biofertilizers for Sustainable Agriculture and Environment: Soil Biology; Giri, B., Prasad, R., Wu, Q.S., Varma, A., Eds.; Springer: Cham, Switzerland, 2019; Volume 55. [CrossRef]

4. Woo, S.L.; Pepe, O. Microbial consortia: Promising probiotics as plant biostimulants for sustainable agriculture. Front. Plant Sci. 2018, 9, 1801. [CrossRef] [PubMed]

5. Vinale, F.; Sivasithamparam, K.; Ghisalberti, E.L.; Marra, R.; Woo, S.L.; Lorito, M. Trichoderma-plant-pathogen interactions. Soil Biol. Biochem. 2008, 40, 1-10. [CrossRef]

6. Harman, G.E.; Howell, C.R.; Viterbo, A.; Chet, I.; Lorito, M. Trichoderma species, opportunistic avirulent plant symbionts. Nat. Rev. Microbiol. 2004, 2, 43-56. [CrossRef] [PubMed]

7. Lorito, M.; Woo, S.L.; Harman, G.E.; Monte, E. Translational research on Trichoderma: From Omics to the field. Ann. Rev. Phytopathol. 2010, 48, 395-417. [CrossRef] [PubMed]

8. Vinale, F.; Sivasithamparam, K. Beneficial effects of Trichoderma secondary metabolites on crops. Phytother. Res. 2020, 34, 2835-2842. [CrossRef]

9. Siddiquee, S. Recent advancements on the role and analysis of volatile compounds (VOCs) from Trichoderma. In Biotechnology and Biology of Trichoderma; Gupta, V.K., Schmoll, M., Herrera-Estrella, A., Upadhyay, R.S., Druzhinina, I., Tuohy, M.G., Eds.; Elsevier Press: Cambridge, MA, USA, 2014; pp. 139-175.

10. Coppola, M.; Cascone, P.; Chiusano, M.L.; Colantuono, C.; Lorito, M.; Pennacchio, F.; Rao, R.; Woo, S.L.; Guerrieri, E.; Digilio, M.C. Trichoderma harzianum enhances tomato indirect defense against aphids. Insect Sci. 2017, 24, 1025-1033. [CrossRef] [PubMed]

11. Turlings, T.C.; Loughrin, J.H.; McCall, P.J.; Rose, U.S.; Lewis, W.J.; Tumlinson, J.H. How caterpillar-damaged plants protect themselves by attracting parasitic wasps. Proc. Natl. Acad. Sci. USA 1995, 92, 4169-4174. [CrossRef]

12. Kessler, A. Defensive function of herbivore-induced plant volatile emissions in nature. Science 2001, 291, 2141-2144. [CrossRef]

13. Dicke, M.; van Poecke, R.M.P.; de Boer, J.G. Inducible indirect defence of plants: From mechanisms to ecological functions. Basic Appl. Ecol. 2003, 4, 27-42. [CrossRef] 
14. Ranieri, E.; Ruschioni, S.; Riolo, P.; Isidoro, N.; Romani, R. Fine structure of antennal sensilla of the spittlebug Philaenus spumarius L. (Insecta: Hemiptera: Aphrophoridae). I. Chemoreceptors and thermo-/hygroreceptors. Arthropod. Struct. Dev. 2016, 45, 432-439. [CrossRef]

15. Baccouri, O.; Bendini, A.; Cerretani, L.; Guerfel, M.; Baccouri, B.C.; Lercker, G.; Zarrouk, M.; Daoud Ben Miled, D. Comparative study on volatile compounds from Tunisian and Sicilian monovarietal virgin olive oils. Food Chem. 2008, 111, 322-328. [CrossRef] [PubMed]

16. Campeol, E.; Flamini, G.; Chericoni, S.; Catalano, S. Volatile Compounds from Three Cultivars of Olea europaea from Italy. J. Agric. Food Chem. 2001, 49, 5409-5411. [CrossRef] [PubMed]

17. Sabatini, N.; Marsilio, V. Volatile compounds in table olives (Olea europaea L.; Nocellara del Belice cultivar). Food Chem. 2008, 107, 1522-1528. [CrossRef]

18. Masi, E.; Romani, A.; Pandolfi, C.; Heimler, D.; Mancuso, S. PTR-TOF-MS analysis of volatile compounds in olive fruits. J. Sci. Food Agric. 2015, 95, 1428-1434. [CrossRef] [PubMed]

19. Sansone-Land, A.; Takeoka, G.R.; Shoemaker, C.F. Volatile constituents of commercial imported and domestic black-ripe table olives (Olea europaea). Food Chem. 2014, 149, 285-295. [CrossRef]

20. Servili, M.; Esposto, S.; Lodolini, E.M.; Selvaggini, R.; Taticchi, A.; Urbani, S.; Montedoro, G.; Serravalle, M.; Gucci, R. Irrigation effects on quality, phenolic composition and selected volatiles of virgin olive oil cv. Leccino. J. Agric. Food Chem. 2007, 55, 6609-6618. [CrossRef]

21. Campeol, E.; Flamini, G.; Cioni, P.L.; Morelli, I.; Cremonini, R.; Ceccarini, L. Volatile fractions from three cultivars of Olea europaea L. collected in two different seasons. J. Agric. Food Chem. 2003, 51, 1994-1999. [CrossRef]

22. Dini, I.; Graziani, G.; Fedele, F.L.; Sicari, A.; Vinale, F.; Castaldo, L.; Ritieni, A. An Environmentally Friendly Practice Used in Olive Cultivation Capable of Increasing Commercial Interest in Waste Products from Oil Processing. Antioxidants $2020,9,466$.

23. Dini, I.; Graziani, G.; Fedele, F.L.; Sicari, A.; Vinale, F.; Castaldo, L.; Ritieni, A. Effects of Trichoderma biostimulation on the phenolic profile of extra-virgin olive oil and olive oil by-products. Antioxidants 2020, 9, 284. [CrossRef] [PubMed]

24. Dini, I.; Graziani, G.; Gaspari, A.; Fedele, F.L.; Sicari, A.; Vinale, F.; Cavallo, P.; Lorito, M.; Ritieni, A. New Strategies in the Cultivation of Olive Trees and Repercussions on the Nutritional Value of the Extra Virgin Olive Oil. Molecules 2020, $25,2345$. [CrossRef] [PubMed]

25. Caruso, G.; Rapoport, H.F.; Gucci, R. Long-term evaluation of yield components of young olive trees during the onset of fruit production under different irrigation regimes. Irrig. Sci. 2013, 31, 37-47. [CrossRef]

26. Massolo, L.; Rehwagen, M.; Porta, A.; Ronco, A.; Herbarth, O.; Mueller, A. Indoor-outdoor distribution and risk assessment of volatile organic compounds in the atmosphere of industrial and urban areas. Environ. Toxicol. 2010, 25, 339-349. [CrossRef]

27. Kesen, S.; Kelebek, H.; Selli, S. Characterization of the Volatile, Phenolic and Antioxidant Properties of Monovarietal Olive Oil Obtained from cv. Halhali. J. Am. Oil Chem. Soc. 2013, 90, 1685-1696. [CrossRef]

28. Angerosa, F. Influence of volatile compounds on virgin olive oil quality evaluated by analytical approaches and sensor panels. Eur. J. Lipid Sci. Technol. 2002, 104, 639-660. [CrossRef]

29. Lin, P.; Cai, J.; Li, J.; Sang, W.; Su, Q. Constituents of the essential oil of Hemerocallis flava day lily. Flavour Fragr. J. 2003, 18, 539-541. [CrossRef]

30. Vichi, S.; Guadayol, J.M.; Caixach, J.; López-Tamames, E.; Buxaderas, S. Comparative study of different extraction techniques for the analysis of virgin olive oil aroma. Food Chem. 2007, 105, 1171-1178. [CrossRef]

31. Üçüncüoğlu, D.; Sivri-Özay, D. Geographical origin impact on volatile composition and some quality parameters of virgin olive oils extracted from the "Ayvalık" variety. Heliyon 2020, 6, e04919. [CrossRef]

32. Zhang, Y.-R.; Wang, R.; Yu, L.-F.; Lu, P.-F.; Luo, Y.-Q. Identification of Caragana plant volatiles, overlapping profiles, and olfactory attraction to Chlorophorus caragana in the laboratory. J. Plant Interact. 2015, 10, 41-50. [CrossRef]

33. Ben Abdeljelil, Z.; Tekaya, M.; Mechri, B.; Flamini, G.; Hammami, M. Changes in volatiles of olive tree Olea europaea according to season and foliar fertilization. Int. J. Agric. Biol. 2017, 19, 1633-1639.

34. Malheiro, R.; Casal, S.; Cunha, S.C.; Baptista, P.; Pereira, J.A. Identification of leaf volatiles from olive (Olea europaea) and their possible role in the ovipositional preferences of olive fly, Bactrocera oleae (Rossi) (Diptera: Tephritidae). Phytochemistry 2016, 121, 11-19. [CrossRef]

35. Ribes, A.; Carrera, G.; Gallego, E.; Roca, X.; Berenguer, M.J.; Guardino, X. Development and validation of a method for air-quality and nuisance odors monitoring of volatile organic compounds using multi-sorbent adsorption and gas chromatography/mass spectrometry thermal desorption system. J. Chromatog. A 2007, 1140, 44-55. [CrossRef] [PubMed]

36. Gallego, E.; Roca, F.J.; Perales, J.F.; Guardino, X. Comparative study of the adsorption performance of an active multi-sorbent bed tube (Carbotrap, Carbopack X, Carboxen 569) and a Radiello ${ }^{\circledR}$ diffusive sampler for the analysis of VOCs. Talanta 2011, 85, 662-672. [CrossRef] [PubMed]

37. Baratella, V.; Volpe, D.; Marucchini, C.; Pucci, C. Early attempts to detect VOCs emission from Olea europaea L. (Laurales: Oleaceae) in different phenological growth stages. Integrated Protection of Fruit Crops Subgroups Pome fruit arthropods and Stone fruits. IOBC/wprs Bull. 2012, 74, 233-240.

38. Flamini, G.; Cioni, P.L.; Morelli, I. Volatiles from Leaves, Fruits, and Virgin Oil from Olea europaea Cv. Olivastra Seggianese from Italy. J. Agric. Food Chem. 2003, 51, 1382-1386. [CrossRef] 
39. Lee, S.; Yap, M.; Behringer, G.; Hung, R.; Bennet, J.W. Volatile organic compounds emitted by Trichoderma species mediate plant growth. Fungal Biol. Biotechnol. 2016, 3, 7. [CrossRef] [PubMed]

40. Asaph, A.; Jongsma, M.A.; Kim, T.-Y.; Ri, M.-B.; Giri, A.P.; Verstappen, W.A.; Schwab, W.; Bouwmeester, H.J. Metabolic engineering of terpenoid biosynthesis in plants. Phytochem. Rev. 2006, 5, 49-58.

41. Erasto, P.; Viljoen, A.M. Limonene-A review: Biosynthetic, ecological and pharmacological relevance. Nat. Prod. Commun. 2008, 3, 1193-1202. [CrossRef]

42. Langenheim, J.H. Higher plant terpenoids: A phytocentric overview of their ecological roles. Chem. Ecol. J. 1994, 20, 1223-1280. [CrossRef]

43. Sadof, C.S.; Grant, G.G. Monoterpene composition of Pinus sylvestris varieties resistant and susceptible to Dioryctria zimmermani. Chem. Ecol. J. 1997, 23, 1917-1926. [CrossRef]

44. Cates, R.G.; Redak, R.A. Variation in the terpene chemistry of Douglas-fir and its relationship to western spruce budworm success. In Chemical Mediation of Coevolution; Spencer, K.C., Ed.; Academic Press: San Diego, CA, USA, 1998; pp. 317-344.

45. Yu, X.; Lin, H.; Wang, Y.; Lv, W.; Zhang, S.; Qian, Y.; Deng, Y.; Feng, N.; Yu, H.; Quan, B. D-limonene exhibits antitumor activity by inducing autophagy and apoptosis in lung cancer. Onco Targets Ther. 2018, 11, 1833-1847. [CrossRef] [PubMed]

46. Yilmaz, B.S.; Özbek, H. Investigation of the anti-inflammatory, hypoglycemic activity and median lethal dose (LD50) level of limonene in mice and rats. ACTA Pharm. Sci. 2018, 56, 85-94. [CrossRef]

47. Shah, B.B.; Mehta, A.A. In vitro evaluation of antioxidant activity of d-limonene. Asian J. Pharm. Sci. 2018, 4, 883-887. [CrossRef]

48. Bai, J.; Zheng, Y.; Wang, G.; Liu, P. Protective effect of d-limonene against oxidative stress-induced cell damage in human lens epithelial cells via the p38 pathway. Oxid. Med. Cell. Longev. 2016, 14, 1-12. [CrossRef] [PubMed]

49. Pathirana, H.N.K.S.; Wimalasena, S.H.M.P.; De Silva, B.C.J.; Hossain, S.; Heo, G.J. Antibacterial activity of lime (Citrus aurantifolia) essential oil and limonene against fish pathogenic bacteria isolated from cultured olive flounder (Paralichthys oilvaceus). Fisher. Aquat. Life 2018, 26, 131-139. [CrossRef]

50. Dias, A.L.B.; Sousa, W.C.; Batista, H.R.F.; Alves, C.C.F.; Souchie, E.L.; Silva, F.G.; Pereira, P.S.; Sperandio, E.M.; Cazal, C.M.; Forim, M.R.; et al. Chemical composition and in vitro inhibitory effects of essential oils from fruit peel of three Citrus species and limonene on mycelial growth of Sclerotinia sclerotiorum. Braz. J. Biol. 2019, 80. [CrossRef]

51. Penuelas, J.; Asensio, D.; Tholl, D.; Wenke, K.; Rosenkranz, M.; Piechulla, B.; Schnitzler, J.P. Biogenic volatile emissions from the soil. Plant Cell Environ. 2014, 37, 1866-1891. [CrossRef] [PubMed]

52. Lawo, N.C.; Weingart, G.J.; Schuhmacher, R.; Forneck, A. The volatile metabolome of grapevine roots: First insights into the metabolic response upon phylloxera attack. Plant Physiol. Biochem. 2011, 49, 1059-1063. [CrossRef]

53. Zhang, J.; Sun, H.; Chen, S.; Zeng, L.; Wang, T. Anti-fungal activity, mechanism studies on $\alpha$-Phellandrene and Nonanal against Penicillium cyclopium. Bot. Stud. 2017, 58, 1-9. [CrossRef]

54. Zhang, J.; Zeng, L.; Sun, H.; Chen, S.; Wang, T.; Ma, S. Use of Nonanal-wax as Postharvest Fungicide of Tomato against Botrytis cinereal. J. Food Nutr. Res. 2017, 5, 458-466. [CrossRef]

55. Twidle, A.M.; Barker, D.; Seal, A.G.; Fedrizzi, B.; Suckling, D.M. Identification of floral volatiles and pollinator responses in kiwifruit cultivars, Actinidia chinensis var. chinensis. J. Chem. Ecol. 2018, 44, 406-415. [CrossRef] [PubMed]

56. Egigu, M.C.; Ibrahim, M.A.; Yahya, A.; Holopainen, J.K. Cordeauxia edulis and Rhododendron tomentosum extracts disturb orientation and feeding behavior of Hylobius abietis and Phyllodecta laticollis. Entomol. Exp. Appl. 2011, 138, 162-174. [CrossRef]

57. Wang, C.; Li, G.; Miao, C.; Zhao, M.; Wang, B.; Guo, X. Nonanal modulates oviposition preference in female Helicoverpa assulta (Lepidoptera: Noctuidae) via the activation of peripheral neurons. Pest Manag. Sci. 2020, 76, 3159-3167. [CrossRef]

58. Zavala-Sanchez, M.A.; Perez-Gutierrez, S.; Perez-Gonzalez, C.; Sanchez-Saldivar, D.; Arias-Garcia, L. Antidiarrheal activity of nonanal, an aldehyde isolated from Artemisia ludoviciana. Pharm. Biol. 2002, 40, 263-268. [CrossRef]

59. Kougan, G.B.; Tabopda, T.; Kuete, V.; Verpoorte, R. Simple phenols, phenolic acids, and related esters from the medicinal plants of Africa. In Medicinal Plant Research in Africa. Pharmacology and Chemistry; Kuete, V., Ed.; Elsevier Inc.: San Diego, CA, USA, 2013; pp. 54-58.

60. Vinale, F.; Manganiello, G.; Nigro, M.; Mazzei, P.; Piccolo, A.; Pascale, A.; Ruocco, M.; Marra, R.; Lombardi, N.; Lanzuise, S.; et al. A novel fungal metabolite with beneficial properties for agricultural applications. Molecules 2014, 19, 9760-9772. [CrossRef] [PubMed]

61. Pascale, A.; Vinale, F.; Manganiello, G.; Nigro, M.; Lanzuise, S.; Ruocco, M.; Marra, R.; Lombardi, N.; Woo, S.L.; Lorito, M. Trichoderma and its secondary metabolites improve yield and quality of grapes. Crop Prot. 2017, 92, 176-181. [CrossRef]

62. Vinale, F.; Sivasithamparam, K.; Ghisalberti, E.L.; Marra, R.; Barbetti, M.J.; Li, H.; Woo, S.L.; Lorito, M. A novel role for Trichoderma secondary metabolites in the interactions with plants. Phys. Mol. Plant Pathol. 2008, 72, 80-86. [CrossRef]

63. Van den Berg, R.A.; Hoefsloot, H.C.; Westerhuis, J.A.; Smilde, A.K.; van der Werf, M.J. Centering, scaling, and transformations: Improving the biological information content of metabolomics data. BMC Genom. 2006, 8, 7-142. [CrossRef] 